\title{
Meningkatkan Hasil Belajar IPS melalui Model Pembelajaran Problem Based Instruction di Sekolah Dasar
}

\author{
Maria Laetisia \\ SD Inpres Wairklau, Sikka, Nusa Tenggara Timur \\ Emil: laestisiamaria@gmail.com
}

\begin{abstract}
Abstrak
Penelitian ini dilatarbelakangi oleh hasil ulangan harian siswa secara klasikal masih di bawah standar KKM pada mata pelajaran IPS pada topik pembahasan kenampakan alam dan buatan. Rendahnya hasil belajar siswa dipengaruhi oleh kecenderungan siswa bosan dalam mengikuti pembelajaran. Upaya untuk meningkatkan hasil belajar siswa terhadap pembelajaranProblem Based Instruction sebagai alternatif dalam memecahkan suatu masalah. Dalam penelitian ini di gunakan metode Penelitian Tindakan Kelas, dengan alat yang digunakan lembar evaluasi, lembar observasi penilaian RPP, lembar penilaian pelaksanaan pembelajaran, lembar penilaian motivasi siswa dan lembar keusioner. Berdasarkan hasil penelitian bahwa hasil motivasi siklus I siswa yang tuntas mencapai KKM berjumlah 15 orang atau 45,45\%, sedangkan pada siklus II siswa yang tuntas mencapai KMM berjumlah 33 atau $100 \%$. Berdasarkan penelitian yang dilaksanakan dengan Model Pembelajaran Problem Based Instruction (PBI) dapat meningkat. Hasil penelitian ini dapat dijadikan sebagai salah satu alternatif bagi guru untuk meningkatkan kualitas pembelajaran di sekolah dasar.
\end{abstract}

Kata Kunci: Pembelajaran Problem Based Instruction, Hasil Belajar, Siswa.

\section{Improving Social Studies Learning Outcomes through Problem Based Instruction Learning Model on Primary Schools}

\author{
Maria Laetisia \\ Wairklau Inpres Elementary School, Sikka, Nusa Tenggara Timur \\ Email: laestisiamaria@gmail.com
}

\begin{abstract}
This research is motivated by the results of students' daily tests are still classically below the KKM standard on social studies subjects on the topic of natural and artificial appearance discussion. The low student learning outcomes are influenced by the tendency of students to get bored in participating in learning. Efforts to improve student learning outcomes towards learning Problem Based Instruction as an alternative in solving a problem. In this study the Classroom Action Research method was used, with the tools used evaluation sheets, RPP assessment observation sheets, learning implementation assessment sheets, student motivation assessment sheets and questionnaire sheets. Based on the results of the study that the results of motivation in the first cycle of students who completed the KKM totaled 15 people or $45.45 \%$, while in the second cycle the students who completed the KMM totaled 33 or $100 \%$. Based on research conducted with the Problem Based Instruction (PBI) Learning Model can be increased. The results of this study can be used as an alternative for teachers to improve the quality of learning in primary schools.

Keywords: Problem Based Instruction Learning, Learning Outcomes, Students.
\end{abstract}




\section{PENDAHULUAN}

Pendidikan memiliki peran yang sangat penting dalam kehidupan manusia. Pendidikan dapat mempengaruhi perkembangan manusia dalam seluruh aspek kepribadian dan kehidupannya. Pendidikan memiliki kekuatan yang dinamis dalam kehidupan manusia di masa depan. Pendidikan dapat mengembangkan berbagi potensi yang dimiliki manusia secara optimal, yaitu mengembangkan potensi yang setinggi-tingginya dalam aspek fisik, intelektual, emosional, sosial, dan spiritual sesuai dengan tahap perkembangan serta karakteristik lingkungan fisik dan lingkungan sosiobudaya dimana dia hidup.

Menurut Driyakara (Mikarsa,2007:1.2) pendidikan adalah upaya memanusiakan manusia muda. Sedangkan menurut Undang-undang Sistem Pendidikan Nasional Pasal 1 Ayat 1 menyatakan bahwa "Pendidikan adalah usaha sadar untuk menyiapkan peserta didik melalui kegiatan bimbingan, pengajaran, dan latihan bagi peranannya di masa yang akan datang".Menurut Kurniasih (2010:1) pendidikan berfungsi untuk memanusiakan manusia, bersifat normatif, dan karena itu mesti dapat dipertanggungjawabkan. Praktek pendidikan tidak boleh dilaksanakan secara sembarang, tetapi harus dilaksanakan secara disadari dan terencana.

Praktek pendidikan harus memiliki suatu landasan yang kokoh agar jelas dan benar konsepnya, tetap tujuan dan saranaannya, relevan isi kurikulumnya, serta efisien dan efektif cara-cara pelaksanaannya. Implikasi dari hal tersebut maka dalam rangkan pendidikan mesti terdapat momen berpikir dan momen bertindak, mesti terdapat momen studi pendidikan dan momen praktek pendidikan.

Dalam kehidupan modern lembaga pendidikan sekolah mempunyai peran penting dalam mengembangkan sumber daya manusia. Sekolah sering juga dipandang sebagai lingkunngan pendidikan kedua bagi anak setelah lingkungan keluarga, diserahi tanggungjawab pendidikan yang dipikul oleh orang tua dalam kelurga. Hal ini terjadi karena orang tua sudah kecil kemungkinan untuk mendidik anaknya untuk menguasai berbagai kemampua yang diperlukan dalam kehidupan.

Sekolah merupakan suatu lembaga khusus, suatu wahana, suatu tempat untuk menyelenggarakan pendidikan, yang di dalamnya terdapat suatu proses belajar mengajar untuk mencapai tujuan pendidikan yang sesuai dengan Pasal 3 Undang-Undang No.20 Tahun 2003 tentang Sistem Pendidikan Nasional. Tujuan dari diselenggarakan disekolah dasar adalah untuk mengembangkan sikap dan kemampuan serta memberikan pengetahuan dan keterampilan dasar 
yang diperlukan serta mempersiapkan siswa mengikuti pendidikan menengah. Untuk mencapai tujuan tersebut, maka diperlukan pendidikan dan pengajaran berbagai disiplin ilmu salah satunya adalah Ilmu Pengetahuan Sosial (IPS).

Ilmu Pengetuan Sosial merupakan ilmu yang sangat berkaitan erat dengan kehidupan sosial bermasyarakat. Globalisasi yang terus berkembang, mempengaruhi gaya kehidup sosial bermasyarakat. Untuk menyeimbangkan kehidupan sosial bermasyarakat agar tradisi kehidupan sosial di Indonesia tidak aterkikis dengan budaya luar, perlu ditanamkan kesadaran akan nilainilai sosial di lingkungannya. Untuk itu, perlu ditanamkan pembelajaran IPS sejak dini.

Permasalahan yang muncul dari kondisi pembelajaran IPS tersebut, sebagian siswa menganggap mata pelajaran IPS sebagai mata pelajaran yang sulit dipahami sehingga siswa cenderung merasa bosan, jenuh dan malas untuk belajar, siswa kurang termotivasi karena menganggap mata pelajaran IPS merupakan mata pelajaran yang membutuhkan pemahaman konsep yang luas. Sehingga aktivitas siswa yang rendah ini dapat mempengaruhi hasil belajar siswa. Berlandaskan kesadaran akan tugas dan tujuan, guru IPS harus mampu menghayati segala gejala dan masalah yang timbul dan terjadi dalam kehidupan perkembangan dan penerapan ilmu dan teknologi harus menjadi perhatiannya. Materi dan konsep pelajaran IPS harus digali dari kenyataan-kenyataan yang ada dan terjadi di masyarakat.

Setelah ditelusuri dalam pembelajaran tersebut guru menggunakan metode ceramah, sehingga pada umumnya siswa mengikuti pembelajaran secara pasif sehingga dalam pembelajaran tersebut keaktifan siswa sangatlah kurang, karena siswa hanya duduk terdiam mendengarkan apa yang di bicarakan. Sehingga siswa kurang aktif dan hasil belajar pun kurang maksimal. Oleh karena itu penelitian ini bertujuan untuk melakukan perubahan proses belajar mengajar untuk berhasilnya tujuan pembelajaran dengan menerapkan suatu sistem pembelajaran yang melibatkan siswa secara aktif dalam kegiatan belajar mengajar, pembelajaran yang semula berpusat pada guru beralih berpusat pada siswa, yaitu salah satunya adalah dengan menggunakan model pembelajaran Problem Based Instruction.

\section{METODE}

Rancangan yang ditetapkan dalam penelitian ini adalah Penelitian Tindakan Kelas. Aqib, dkk (2010:3) mendefinisikan PTK sebagai penelitian yang dilakukan oleh guru dikelasnya sendiri melalui refleksi diri dengan tujuan untuk memperbaiki kinerjanya sehingga hasil belajar siswa meningkat. Selanjutnya, Arikunto, dkk (2009:140) menerangkan bahwa dalam 
pelaksanaan PTK terdapat empat tahapan, yaitu perencanaan, pelaksanaan tindakan, pengamatan danrefleksi ataupantulan.Seperti yang digambarkan dalam skema berikut ini:

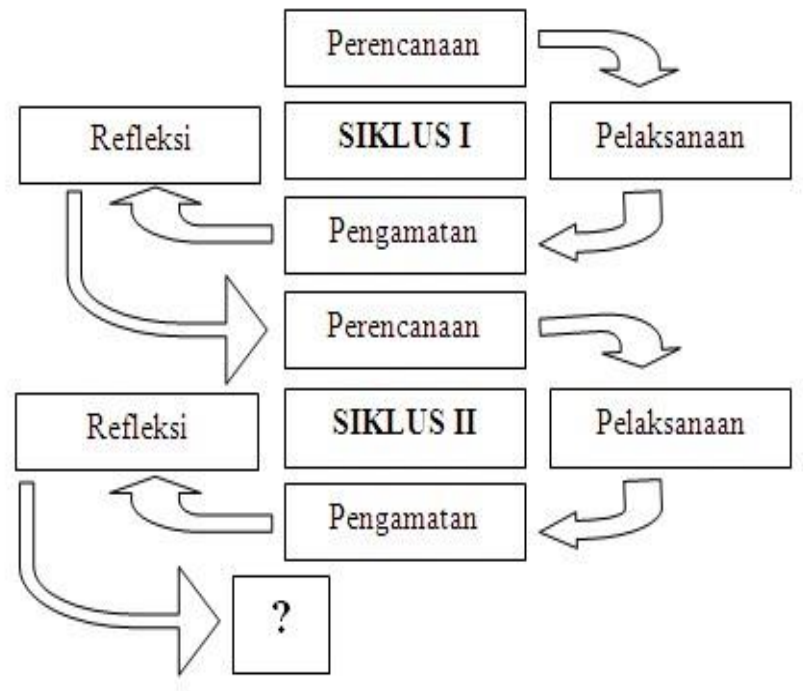

Gambar 1. Bagan Langkah-Langkah PTK (Arikunto, 2009:16)

Subjek penelitian dalam penelitian tindakan kelas ini adalah siswa kelas VA SD Inpres Wairklau, yang terletak di Jln. Cempaka, Perumnas, Kecamatan Alok, Kabupaten Sikka. Adapun jumlah siswa yang diteliti adalah 33 orang, terdiriatas17 siswa laki-lakidan16siswa perempuan.

Teknik pengumpulan data yang digunakan dalam penelitian ini adalah teknik tes dan non tes.

Tes yang akan dilakukan dalam penelitian ini adalah tes tertulis yang dilaksanakan pada setiap akhir siklus. Sementara untuk non-tes digunakan Observasi, dokumentasi, dan wawancara. Dalam penelitian tindakan kelas, observasi terutama ditujukan untuk memantau proses dan dampak perbaikan yang direncanakan. Observasi digunakan untuk mengamati aktivitas siswa dan guru dalam prosespembelajaranyang menggunakan Model PBI. Lembarobservasi dilakukan untuk mengetahui bagaimana kualitas pembelajaran yang dilaksanakan di dalam kelas. Alat penilaiannya adalah menggunakanlembar pengamatan aktivitas siswa. Observasi juga dilakukuan terhadap guruyang sedang mengajar dengan lembar pengamatan keterampilan guru.

Dokumen yang telah diperoleh kemudian dianalisis (diurai), dibandingkandan dipadukan (sintesis) membentuk satu hasil kajian yang sistematik, dan utuh. Jadi metode dokumenter tidak sekedar mengumpulkan dan menulis kan atau melaporkan dalam bentuk kutipan-kutipan tentang sejumlah dokumenyang dilaporkan dalam penelitian adalah hasil analisis terhadap dokumen-dokumen tersebut. Wawancara yaitu salah satu alat penilaian non tes yang digunakan untuk mendapat kan informasi tertentu tentang keadaan responden dengan cara tanya jawab 
sepihak (Hamdani, 2011:318). Wawancara dalam penelitian ini digunakan untuk mengetahui pendapat guru dan siswa kelas VA SD Inpres Wairklau tentang pembelajaran yang telah dilakukan. Wawancara dilakukan pada setiap akhir pembelajaran pada masing- masing pertemuan dalam tiap siklus I dan siklus II.

Teknik analisis data yang digunakan adalah analisis kuantitatif dan kualitatif. Data kuantitatif berupa hasil belajar kognitif, dianalisis dengan menggunakan teknik analisis deskriptif dengan menentukan mean atau rerata. Adapun penyajian data kuantitatif dipaparkan dalam bentuk presentase. Adapun persentase tersebut adalah sebagai berikut: Hasil penghitungan dikonsultasikan dengan kriteria ketuntasanbelajar siswa yang dikelompokkan kedalam dua kategori tuntas dan tidak tuntas, dengan kriteria sebagai berikut.

Tabel 1.Kriteria Ketuntasan Minimal Belajar Siswa

\begin{tabular}{ccc}
\hline & Kriteria & Kualifikasi \\
\hline Klasikal & Individual & Tuntas \\
\hline$\geq 75 \%$ & $\geq 70$ & TidakTuntas \\
\hline$<75 \%$ & $<70$ &
\end{tabular}

Data kualitatif berupa data hasil observasi keterampilan guru dan aktifitas siswa dalam pembelajaran IPSmelalui model Problem Based Instruction, serta hasil catatan lapangan dan wawancara dianalisis dengan analisis deskriptif kualitatif. Data kualitatif dipaparkan dalam kalimat yang dipisah- pisahkan menurut kriteria untuk memperoleh kesimpulan. Dalam penelitian ini data kualitatif diperoleh dari hasil observasi terhadap aktifitas guru dan siswa serta hasil wawancara siswa sebagai bentuk respon terhadap pembelajaran yang dilakukan guru.

Kualitas Pembelajaran IPS melalui Model PBI (Problem Based Instruction) dikelas VA SD Inpres Wairklau dapat dikatakan meningkatdengan indikator keberhasilan sebagai berikut. (a) Aktivitas siswa dalam pembelajaran IPS melalui Model PBI meningkat, dengan kriteria minimal baik; (b) Keterampilan guru dalam pembelajaran IPS melalui Model PBI meningkat, dengan kriteria minimal baik; (c) $85 \%$ siswa kelasVA SD Inpres Wairklau mengalami ketuntasan belajar individual sebesar $\geq 60$ dalam pembelajaran IPS menggunakan model PBI. 


\section{HASIL DAN PEMBAHASAN}

\section{Hasil Penelitian Siklus I}

\section{Keterampilan guru dalam pembelajaran IPS}

Hasil observasi keterampilan guru dalam pembelajaran IPS melalui model pembelajaran Problem Based Instruction pada siklus I diperolehdata sebagai berikut:

Tabel 2. Data Hasil Observasi Keterampilan Guru Siklus I

\begin{tabular}{llll}
\hline No & \multicolumn{1}{c}{ Indikator } & skor & Kriteria \\
& & & \\
\hline 1 & Mempersiapkan siswauntuk belajar & 3 & B \\
2 & Melakukan apersepsi & 3 & B \\
3 & Menyampaikan tujuan pembelajaran & 2 & C \\
4 & Memunculkan permasalahan kepadasiswamelaluidemonstrasi atau & 3 & B \\
& cerita & 2 & C \\
5 & Membimbingsiswadalam melaksanakaneksperimen & 2 & C \\
6 & Membimbingsiswadalam merencanakan karya. & 2 & C \\
7 & Membimbingsiswadalam mempresentasikan karya & 3 & B \\
8 & Melakukan Tanyajawab & 4 & A \\
9 & Memberi penguatan & 3 & B \\
10 & Menutup pelajaran & 27 & Baik \\
\hline & $\quad$ Jumlah SkorTotal & & \\
\hline
\end{tabular}

Berdasarkan tabel diatas, dapat dilihat bahwa jumlah skor keterampilan mengajar yang dicapai guru dalam penelitian menggunakan model Problem Based Instruction pada siklus I, diperoleh skor 27, rerata 2,7 dengan kategoriB (baik).Hal ini ditunjukkan dengan guru melakukan presensi untuk mengecek kehadiran siswa, selain itu guru juga menyiapkan peralatan media yang akan digunakan selama pembelajaran. Guru mengajak siswa untuk menyanyikan lagu naik delman untukmemunculkan materi kepadas iswa dengan cara yang kongkrit, menyenangkan bagi siswa. Gambar delman ditampilkan di depan kelas untuk menarik perhatian siswa. Tingkat keterlihatan gambar sudah baik, terbukti siswa yang paling belakang bisa melihat gambar delman dengan jelas. Gambar yang disajikan juga sesuai dengan materi. Guru sudah menyampaikan tujuan pembelajaran. Guru memunculkan masalah melalui lisan dan bantuan media gambar yang dibawa oleh guru. Guru sudah membimbing dan mengawasi jalannya eksperimen siswa.

\section{Aktivitas Siswa}

Hasil observasi aktivitas siswa dalam pembelajaran IPS melalui model pembelajaran Problem Based Instruction padasiklus I diperoleh data sebagai berikut: 
Tabel 3. Hasil Observasi Aktivitas Siswa Siklus I

\begin{tabular}{|c|c|c|c|c|c|c|c|c|}
\hline \multirow[t]{2}{*}{ No } & \multirow[t]{2}{*}{ Indikator } & \multicolumn{4}{|c|}{$\begin{array}{c}\text { Jumlah siswa yang } \\
\text { mendapatskor }\end{array}$} & \multirow[t]{2}{*}{$\begin{array}{l}\text { Total } \\
\text { Skor }\end{array}$} & \multirow[t]{2}{*}{$\begin{array}{c}\text { Rata- rata } \\
\text { Skor }\end{array}$} & \multirow[t]{2}{*}{ Kriteria } \\
\hline & & 1 & 2 & 3 & 4 & & & \\
\hline \multirow[t]{2}{*}{1} & Kesiapan & & & & & & & \\
\hline & siswadalammengikutipembelajaranIPS & 2 & 3 & 1 & 4 & 27 & 2.70 & $\mathrm{~B}$ \\
\hline \multirow[t]{2}{*}{2} & Meresponpermasalahanyangdisampaika & & & & & & & \\
\hline & $\mathrm{n}$ oleh guru & 2 & 3 & 3 & 2 & 25 & 2.50 & $\mathrm{~B}$ \\
\hline \multirow[t]{2}{*}{3} & Mengidentifikasi & & & & & & & \\
\hline & masalahyangdisampaikan oleh guru & 2 & 5 & 3 & 0 & 21 & 2.10 & $\mathrm{C}$ \\
\hline \multirow[t]{2}{*}{4} & Melakukan kegiatanpenyelidikan & & & & & & & \\
\hline & kelompok & 1 & 5 & 3 & 1 & 24 & 2.40 & $\mathrm{C}$ \\
\hline 5 & Merencanakan karya & 1 & 3 & 3 & 3 & 28 & 2.80 & $\mathrm{~B}$ \\
\hline 6 & Mempresentasikan karya & 2 & 7 & 1 & 0 & 19 & 1.90 & $\mathrm{C}$ \\
\hline \multirow[t]{2}{*}{7} & Menganalisis proses pemecahan & & & & & & & \\
\hline & masalah & 3 & 1 & 4 & 2 & 25 & 2.50 & $\mathrm{~B}$ \\
\hline \multirow[t]{2}{*}{8} & Menyimpulkan materi & & & & & & & \\
\hline & (kegiatanrefleksi) & 0 & 4 & 4 & 2 & 28 & 2.80 & $\mathrm{~B}$ \\
\hline \multicolumn{2}{|c|}{ Jumlah } & & & & & & 19.70 & Cukup \\
\hline \multicolumn{2}{|c|}{ Kriteria } & & & & & & 2.46 & \\
\hline
\end{tabular}

Berdasarkan hasil observasi aktivitas siswa dalam pembelajaran IPS melalui model pembelajaran Problem Based Instruction pada siklus I di atas, diperoleh jumlah rata-rata skor yaitu 19,50. Sehingga diperoleh rata-rata 2,44. Hasil observasi aktivitas siswa untuk siklus I masuk dalam kriteria cukup (C). ). Hal ini ditunjukkan dengan siswa yang masih sering ramai dan tidak tertib, saat guru masuk ke dalam kelas untuk memulai pelajaran masih ada siswa yang berada diluar ruangan, dan sebagian besar siswa masih sibuk bermain di dalam kelas.

\section{Hasil Belajar Siswa}

Hasil tes pembelajaran IPS melalui model pembelajaran Problem Based Instruction pada siklus I, diperoleh data sebagai berikut.

Tabel 4. Hasil Tes Pembelajaran IPS Siklus I

\begin{tabular}{cccc}
\hline Nilai & Frekuensi & Persentase & Kualifikasi \\
\hline $80-100$ & 5 & $15,15 \%$ & Tuntas \\
$75-80$ & 10 & $30,30 \%$ & Tuntas \\
$42-74$ & 10 & $30,30 \%$ & TidakTuntas \\
$24-41$ & 8 & $24,24 \%$ & TidakTuntas \\
$6-23$ & 0 & $0 \%$ & TidakTuntas \\
\hline Jumlah & 33 & $100 \%$ & \\
\hline
\end{tabular}


Tabel distribusi frekuensi di atas menunjukkan bahwa tes pembelajaran IPS melalui model pembelajaran Problem Based Instruction pada siklus I diperoleh hasil bahwa 45,45\% atau sebanyak 15 siswa dari 33 siswa mengalami ketuntasan belajar sedangkan 54,54\% atau 18 siswa lainnya belum tuntas. Rata-rata nilai yang diperoleh dalamh asil tes pembelajaran IPS adalah sebesar 60 dengan nilai terendah 35 dan nilai tertinggi 85 . Nilai yang paling sering muncul pada siklus I ini adalah nilai antara 42-74 dan nilai antara 75-80.

\section{Hasil Penelitian Siklus II}

\section{Keterampilan Guru dalam Pembelajaran IPS}

Hasil observasi keterampilan guru dalam pembelajaran IPS melalui model pembelajaran Problem Based Instruction pada siklus II diperoleh data sebagai berikut:

Tabel 5. Data Hasil Observasi Keterampilan Guru Siklus II

\begin{tabular}{lllc}
\hline No & Indikator & skor & kriteria \\
\hline 1 & Mempersiapkan siswa untukbelajar & 3 & B \\
2 & Melakukan apersepsi & 3 & B \\
3 & Menyampaikan tujuan pembelajaran & 3 & B \\
4 & Memunculkan permasalahankepadasiswamelaluidemonstrasiataucerita & 3 & B \\
5 & Membimbingsiswa dalammelaksanakan eksperimen & 3 & B \\
6 & Membimbingsiswa dalammerencanakan karya. & 3 & B \\
7 & Membimbingsiswa dalammempresentasikan karya & 2 & C \\
8 & Melakukan Tanyajawab & 3 & B \\
9 & Memberipenguatan & 4 & A \\
10 & Menutup pelajaran & 4 & A \\
\hline Jumlah SkorTotal & 31 & baik \\
\hline Rerata & 3.1 & \\
\hline
\end{tabular}

Berdasarkan tabel di atas, dapat dilihat bahwa jumlah skor keterampilan mengajar yang dicapai guru dalam penelitian menggunakan model Problem Based Instruction pada siklus IIdiperoleh skor 31, rerata 3,1 dengan kategori B (baik).

\section{Aktivitas Siswa}

Hasil observasi aktivitas siswa dalam pembelajaran IPS melalui model pembelajaran Problem Based Instruction padasiklus II diperolehdata sebagai berikut. 
Tabel 6. Hasil Observasi Aktivitas Siswa Siklus II

\begin{tabular}{|c|c|c|c|c|c|c|c|c|}
\hline \multirow[t]{2}{*}{ No } & \multirow[t]{2}{*}{ Indikator } & \multicolumn{4}{|c|}{$\begin{array}{c}\text { Jumlah siswa } \\
\text { yang mendapat }\end{array}$} & \multirow{2}{*}{$\begin{array}{c}\text { Jumlah } \\
\text { Total } \\
\text { Skor }\end{array}$} & \multirow{2}{*}{$\begin{array}{l}\text { Rata- } \\
\text { rata } \\
\text { Skor }\end{array}$} & \multirow[t]{2}{*}{ Kriteria } \\
\hline & & 1 & 2 & 3 & 4 & & & \\
\hline \multirow[t]{2}{*}{1} & Kesiapan & & & & & & & \\
\hline & siswadalammengikutipembelajaran & 0 & 3 & 2 & 5 & 32 & 3.20 & $\mathrm{~B}$ \\
\hline \multirow[t]{2}{*}{2} & Meresponpermasalahanyangdisampaik & & & & & & & \\
\hline & an oleh guru & 0 & 4 & 3 & 3 & 29 & 2.90 & $\mathrm{~B}$ \\
\hline 3 & Mengidentifikasi & & & & & & & \\
\hline \multirow[t]{2}{*}{4} & $\begin{array}{l}\text { masalahyangdisampaikan oleh guru } \\
\text { Melakukan kegiatan }\end{array}$ & 1 & 4 & 3 & 2 & 26 & 2.60 & $\mathrm{~B}$ \\
\hline & penyelidikankelompok & 1 & 3 & 3 & 3 & 28 & 2.80 & $\mathrm{~B}$ \\
\hline 5 & Merencanakan karya & 0 & 5 & 1 & 4 & 29 & 2.90 & B \\
\hline 6 & Mempresentasikan karya & 1 & 4 & 5 & 0 & 24 & 2.40 & $\mathrm{C}$ \\
\hline \multirow[t]{2}{*}{7} & Menganalisis prosespemecahan & & & & & & & \\
\hline & masalah & 1 & 3 & 1 & 5 & 30 & 3.00 & $\mathrm{~B}$ \\
\hline \multirow[t]{2}{*}{8} & Menyimpulkan materi & & & & & & & \\
\hline & (kegiatanrefleksi) & 0 & 5 & 1 & 4 & 29 & 2.90 & $\mathrm{~B}$ \\
\hline \multicolumn{2}{|c|}{ Jumlah } & & & & & & 22.70 & \\
\hline \multicolumn{2}{|c|}{ Kriteria } & & & & & & 2.84 & Baik \\
\hline
\end{tabular}

Berdasarkan hasil observasi aktivitas siswa dalam pembelajaran IPS melalui model pembelajaran Prboblem Based Instruction pada siklus II di atas, diperoleh jumlah keseluruhanya itu 22, 70. Sehingga diperoleh rata-rata 2,84. Hasil observasi aktivitas siswa untuk siklus II masuk dalam kriteria baik (B). Hal ini ditunjukkan dengan siswa yang sudah cukup tertib dalam mengikuti pembelajaran, saat guru masuk kedalam kelas untuk memulai pelajaran sudah tidak ada siswa yang berkeliaran diluar kelas, namun ada beberapa siswa yang masih sibuk bermain di dalam kelas, ketika guru melakukan apersepsi dengan cara menanyakan materi pembelajaran pada pertemuan sebelumnya, siswa menjawab pertanyaan guru dengan mudah.

\section{Hasil Belajar Siklus II}

Hasil tes pembelajaran IPS melalui model pembelajaran Problem Based Instruction pada siklus II, diperoleh data sebagai berikut: 
www.journal.univetbantara.ac.id/index.php/ijimm

Tabel 7. Hasil Tes Pembelajaran IPS Siklus II

\begin{tabular}{cccc}
\hline Nilai & Frekuensi & Persentase & Kualifikasi \\
\hline $80-100$ & 20 & $60,60 \%$ & Tuntas \\
$75-80$ & 13 & $39,39 \%$ & Tuntas \\
$42-74$ & 0 & $0 \%$ & TidakTuntas \\
$24-41$ & 0 & $0 \%$ & TidakTuntas \\
$6-23$ & 0 & $0 \%$ & - \\
\hline Jumlah & 33 & $100 \%$ & \\
\hline
\end{tabular}

Tabel distribusi frekuensi di atas menunjukkan bahwa tes pembelajaran IPS melalui model pembelajaran Problem Based Instruction pada siklus II diperoleh hasil bahwa 100\% atau sebanyak 33 siswa siswa mengalami ketuntasan belajar. Rata-rata nilai yang diperoleh dalam hasil tes pembelajaran IPS adalah sebesar 60,48 dengan nilai terendah 77 dan nilai tertinggi 90.

\section{SIMPULAN DAN SARAN}

Berdasarkan hasil penelitian peningkatan kualitas pembelajaran IPS melalui model pembelajaran Problem Based Instruction (PBI) pada siswa kelas VA SD Inpres Wairklau, maka dapat disimpulkan sebagai berikut: (1) Kualitas pembelajaran IPSmelalui model pembelajaran Problem Based Instruction (PBI) pada siswa kelasVASD Inpres Wairklau terjadi peningkatan ditunjukkan dengan keterampilan guru mengalami peningkatan, pada siklusI keterampilan guru baik (B) dengan skor 29, meningkat menjadi baik sekali (A) dengan skor 35 pada siklus II; (2) Aktivitas siswa mengalami peningkatan, pada siklus I aktivitas siswa mendapat skor 19,64 dengan kategori cukup (C) meningkat menjadi baik (B) pada pada siklus II dengan skor 25,19; (3) Hasil belajar siswa mengalami peningkatan, Rata-rata hasil belajar siswa pada siklus I sebesar 60,24 meningkat menjadi 70,71 pada siklus II. Persentase ketuntasan belajar klasikal siswa juga meningkat. Pada siklus I ketuntasan belajar klasikal adalah 52,37 \%, kemudian meningkat menjadi 80,94\% pada siklus II mengalami ketuntasan belajar individual $\geq 70$, maka penelitian ini dinyatakan berhasil.

\section{DAFTAR REFERENSI}

Amien, Mohammad. 1987.Mengajarkan Ilmu PengetahuanAlam Dengan Menggunakan Metode "Discovery" dan “Inquiry”.Jakarta : Depdikbud

Anni, Catharina Tdkk. 2007.Psikologi Belajar. Semarang:UNNES Press.

Arikunto,Suharsimi,dkk.2009.PenelitianTindakanKelas.Jakarta:BumiAksara

Arends, 2008.LearningTo Teach. Yogyakarta: PustakaPelajar

Aqib, Zainal dkk. 2010. Penelitian Tindakan Kelas. Bandung: YramaWidya.

Burhanuddin, Elita. 2009.Media. Jakarta: Depdiknas. 
www.journal.univetbantara.ac.id/index.php/ijimm

Daryanto. 2010.Belajar dan Mengajar. Bandung: Yrama Widya.

Daryanto.2010.MediaPembelajaran.Bandung:SaranaTutorialNuraniSejahtera.

Djamarah,SyaifulBahri.2010.GurudanSiswaDidikDalamInteraksiEdukatif.Jakarta:PT.RinekaCipta

Mansur, S. 2018. Pengaruh Pendekatan Jelajah Alam Sekitar (JAS) Terhadap Hasil Belajar Siswa Pada

Materi Klasifikasi Mahluk Hidup di SMPK Binawirawan Maumere. Uhamka. Bioeduscience. 2 (1): 74-80. DOI: $10.29405 /$ j.bes/74-80121314 